\title{
WestVirginiaUniversity
}

THE RESEARCH REPOSITORY @ WVU

Graduate Theses, Dissertations, and Problem Reports

2018

\section{Children's Perceptions of Pretend Play Over Time}

\author{
Rebekah Kisamore
}

Follow this and additional works at: https://researchrepository.wvu.edu/etd

\section{Recommended Citation}

Kisamore, Rebekah, "Children's Perceptions of Pretend Play Over Time" (2018). Graduate Theses, Dissertations, and Problem Reports. 5986.

https://researchrepository.wvu.edu/etd/5986

This Thesis is protected by copyright and/or related rights. It has been brought to you by the The Research Repository @ WVU with permission from the rights-holder(s). You are free to use this Thesis in any way that is permitted by the copyright and related rights legislation that applies to your use. For other uses you must obtain permission from the rights-holder(s) directly, unless additional rights are indicated by a Creative Commons license in the record and/ or on the work itself. This Thesis has been accepted for inclusion in WVU Graduate Theses, Dissertations, and Problem Reports collection by an authorized administrator of The Research Repository @ WVU. For more information, please contact researchrepository@mail.wvu.edu. 
Children's Perceptions of Pretend Play Over Time

Rebekah Kisamore

Thesis submitted to the College of Education and Human Services

at West Virginia University in partial fulfillment of the requirements for the degree of

Master of Arts in Educational Psychology

With an emphasis in Child Development and Family Studies

Barbara Warash, Ph. D, Chair

Karen Rambo-Hernandez, Ph. D

Jessica Troilo, Ph. D

Department of Learning Sciences and Human Development

Morgantown, West Virginia

2018

Keywords: pretend play, self-assessment, gender, early childhood

Copyright 2018 Rebekah Kisamore 


\section{Abstract \\ Children's Perceptions of Pretend Play Over Time \\ Rebekah Kisamore}

This study examined how age and gender influence children's perceptions of play over time. Participants in the study, 39 children between the ages of three and five, answered pretend play questions pulled from the Play Skills Self Report Questionnaire (PSSRQ). Children in the study were enrolled in either a three or four-year-classroom and were assessed in the Fall of 2016 and again in the Spring of 2017. Two-way repeated measures ANOVA's were used to assess the influence that age and gender have on children's perceptions of pretend play. Results showed that children enrolled in the three-year-old classroom did not assess their play differently than children enrolled in the four-year-old classroom. Results also showed that males and females respond differently when assessing their play. 


\section{Acknowledgement}

I would like to thank my advisor and committee chair person Dr. Barbara Warash. You have helped me achieve what I did not believe was possible. I would also like to thank Dr. Jessica Troilo, and Dr. Karen Rambo-Hernandez for serving on my committee. A special thank you to Karen for being patient while assisting me with statistics. I want to thank my friends and family for supporting me while I completed this degree. A special thank you to Erin Moore, a fellow graduate student who spent many hours encouraging me throughout the writing process. Lastly, I would like to thank Melissa Workman and Keri Law for being excellent mentors, you have helped me become a better educator. 


\section{Table of Contents}

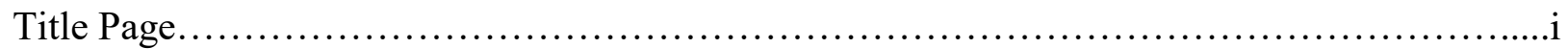

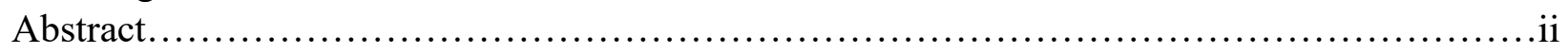

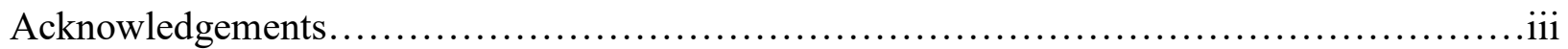

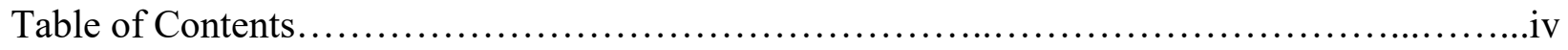

\section{CHAPTER I}

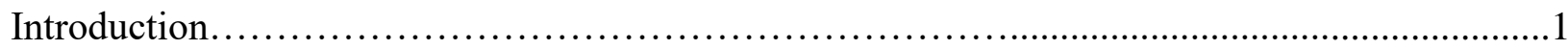

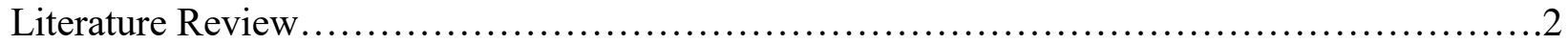

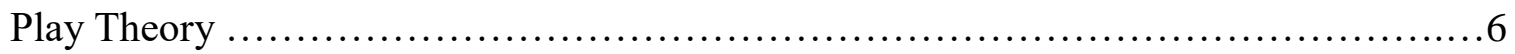

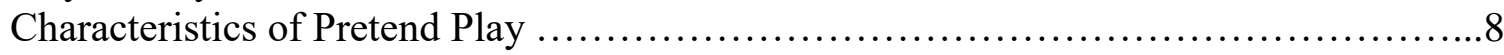

Children's Use of Self-Assessment.............................................. 12

Current Study ....................................................................

\section{CHAPTER II}

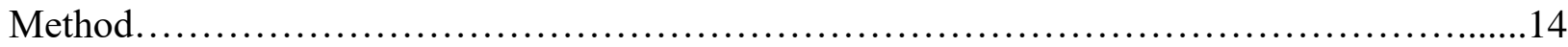

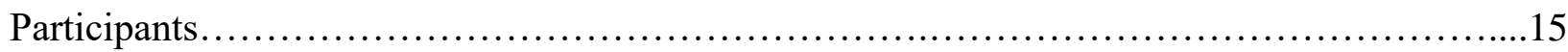

Measures..................................................................... 15

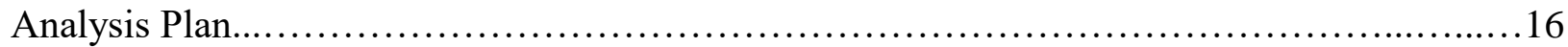

\section{CHAPTER III}

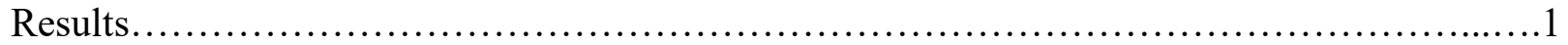

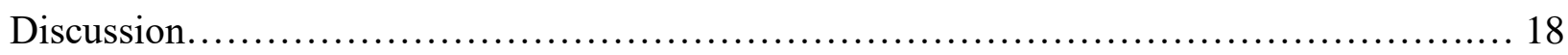

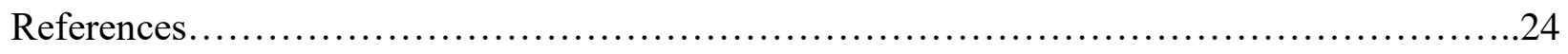

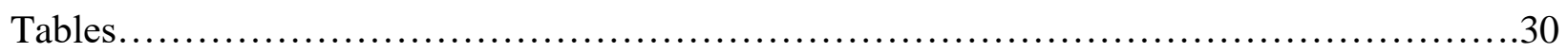

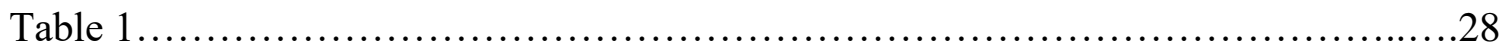

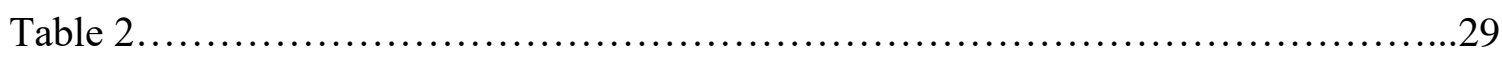

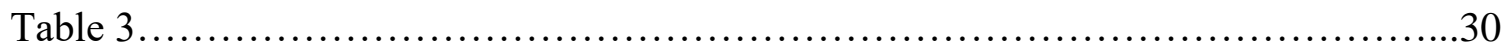

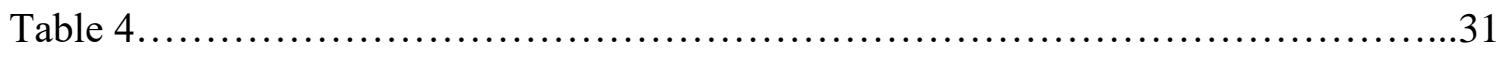

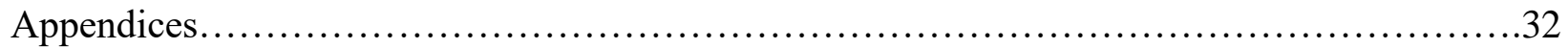

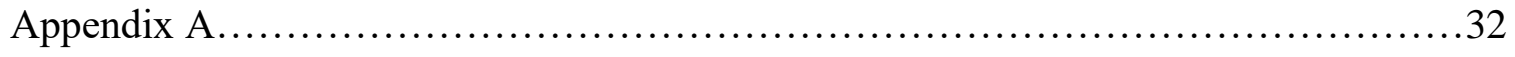

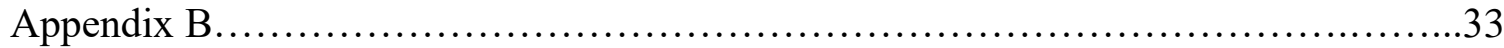




\section{Chapter 1}

\section{Introduction}

The art of play has been a significant component of early childhood across time and can be dated back to the eighteenth century (Cohen, 1993). The research and application of play continues to be studied and is emphasized during early childhood because of its known influence on child development (Sturgess, 2002). Through play, children advance through developmental stages, acquiring skills across the developmental domains. Sturgess (2002) discusses various types of play including: pretend play, exploratory play, functional play, constructive / creative play, and games with rules. The type of play children participate in is dependent on their developmental level, as well as other mediating variables such as gender and environment (Sturgess, 2002).

The current study focused on pretend play, the most prominent form of play seen during the preschool years, stretching from the age of three and ending around the age of five (Leong \& Bodrova, 2003). Pretend play is child driven, enjoyable, active, and engaging (Miller \& Kuhaneck, 2008; Sturgess, 2002). Through pretend play, children engage in social interactions with others, and these interactions support the development of skills such as self-regulation, language, and abstract thinking (Leong and Bodrova, 2003). Piaget (1952) and Vygotsky (1978) have provided explanations as to why pretend play is so prominent during early childhood. On one hand, Piaget described development in stages. Within each stage children develop skills necessary to advance on to subsequent stages. Piaget explained that during the pre-operational stage of development, beginning around the age of three, children start to gain the skills necessary to participate in pretend play (Piaget, 1964). On the other hand, Vygotsky described development as a social construct, and because of this, children learn from their social 
interactions with others, developing the social skills necessary to participate pretend play (Vygotsky, 1978).

Stemming from theoretical explanations of play and development, this study pivoted around the idea that children are the driving force behind their pretend play experiences, and that they are the most reliable source of information regarding young children's perceptions of play. Adults are not present in all contexts; therefore, it is important to understand how children themselves perceive their pretend play (Sturgess, 2002). Oftentimes, children and adults do not have the same idea of what constitutes play, and therefore a child may be engaging in what they perceive to be play, while a present adult may see their behavior as an annoying disruption (Sturgess, 2002). The current study also addressed the influence that gender may have on children's perceptions of pretend play. Van de Sompel, Vermeir, and Pandelaere (2012) conducted a study showing that males and females differ is their play behaviors, and because of this, the current study aimed to address whether boys and girls differ in their perception of pretend play.

Lastly, the study questioned whether the self-assessment of play during the preschool years is feasible based on the developmental capabilities of children between the ages of three and five. To support the questions posed in the study, the definition of play, the developmental progression of children between the ages of three and five, gender differences regarding social and cognitive functioning during play, key characteristics of pretend play, and the use of selfassessment during the pre-school years will be reviewed.

\section{Literature Review}

To fully understand how play fits into child development, it is important to understand what play is (Sutton-Smith, 1997). Play is a difficult construct to define and has been tracked 
throughout time with many types and perceptions of play existing simultaneously among the human species. Play reaches beyond the immediate realm of child development and includes complex neurological processes, as well as biological underpinnings, creating a complex, adaptive system through which children learn. Play does not fit in a box, but transcends beyond a child's physical environment, and as children develop, their new experiences and ideas transform the quality and type of play they participate in. Play does not possess a singular definition but possess variability. Play is unique to the participant and evolves based on the context in which it is present (Sutton-Smith, 1997).

Due to the ambiguity of play, theorists have provided us with a unique understanding and interpretation of the social construct. Elkind (2008) considers play to be an avenue through which individuals can learn, describing a child's social, emotional, and physical play environment as an influential aspect of development. Erikson (1993) described play as a human's way of making sense of their experiences by engaging in the creation of pretend situations, where they can plan and explore various outcomes. Montessori (1965) provides a playful interpretation of play, believing that children have free will regarding their participation in play, and that play involves mental processes that transport children to an imaginary world, free of adult-thinking. While these definitions of play all discuss the influence on child development, it is important to remember that children do not randomly awake with the ability to engage in high level play, rather play develops as children develop (Piaget, 1964).

Theorists such as Piaget and Vygotsky have incorporated the construct of play into their theoretical views of child development. Piaget (1964) describes development in four unique stages: sensory-motor, preoperational representation, concrete operations, and formal operations. Throughout each of these developmental stages, different types of play manifest (Piaget, 1964). 
The current study focuses on pretend play, which builds off the sensory motor stage of development, and which fully forms during the pre-operational stage of development. Therefore, the sensory motor stage of development, as well as the preoperational stage of development will be reviewed.

Throughout the sensory-motor stage, occurring during the first year and a half of life, infants begin to develop skills which will be necessary for future development (Piaget, 1964). Skills such as object permanence, practical space, and causality; the understanding that they can influence their surroundings, pave the way for higher levels of cognitive functioning. During the sensory-motor stage of development children primarily participate in functional play. During functional play, children begin to discover that they can influence their surroundings as they explore their ability to interact with objects in the environment (Piaget, 1964). Children begin to understand that their actions influence their environment, causing them to engage in play behaviors such as throwing a ball, knocking down a cup, or dumping out the contents of a container and then refilling it. The development of functional play is necessary for children to move onto more advanced symbolic and pretend play, which occurs during the preoperational stage of development (Piaget, 1964).

Around the age of two and a half years, children enter what Piaget refers to as the preoperational stage of development (Piaget, 1964). During this stage of development, children begin to develop symbolic functioning. Symbolic functioning refers to a child's ability to recognize and remember objects that are not currently present, while symbolically reenacting these objects using other means. As children progress through this stage of development they develop the ability to think more profoundly about their immediate surroundings (Piaget, 1964). Research has shown that this is due to rapid development in the prefrontal cortex, as well as 
other cortical regions of the brain (Rothbart \& Rueda, 2005). As these cortical regions continue to develop, children begin to demonstrate cognitive skills such as attentional control, cognitive inhibition, inhibitory control, working memory, and cognitive flexibility. These skills are what Rothbart and Rueda (2005) refer to as executive functioning (Rothbart \& Rueda, 2005). The main supporter of executive functioning, the prefrontal cortex, is the driving force behind young children's ability to behave in a manner that is cognitively, as well as behaviorally appropriate (Rothbart \& Rueda, 2005).

This developmental achievement can be seen during symbolic play, where young children begin to reproduce what they observe and experience in their environment using the objects around them (Piaget, 1964). As children continue to move through the preoperational stage of development, they develop cognitive skills necessary to begin using open-ended objects to represent their surroundings. At this point in time, symbolic play transforms into pretend play (Piaget, 1964), the type of play focused on in the current study. To properly engage in pretend play, children must be able to engage in social interactions with others (Vygotsky, 1978), which Ladd, Birch, and Buhs (1999) described as social competence. Social competence is a child's ability to engage in positive interactions with those in their environment while recognizing that others may have feelings different than their own, and with that, exhibiting self-control when faced with difficulties, whether it be their own, or their peers (Ladd, Birch, \& Buhs, 1999). Therefore, for children in Piaget's preoperational stage of development to engage in pretend play, they must be experiencing brain growth in the prefrontal cortex, which supports children's development of age appropriate behaviors as well as social interactions with others (Piaget, 1964; Rothbart \& Rueda, 2005; Ladd, Birch \& Buhs, 1999). 


\section{Vygotsky's Theory of Development}

While Piaget discussed development in terms of stages, Vygotsky possessed a social outlook on development during early childhood, believing that humans have a unique ability to see the world in a deeper, and more meaningful way, and because of this, as children interact with others, they learn to make meaning of the world around them (Vygotsky, 1978). Vygotsky believed that for children to develop, they must engage in social interactions, and it is through these interactions that children will gain the skills necessary to reach a higher developmental level. Throughout his research, Vygotsky discussed three foundational concepts that support child development: social interactions, the zone of proximal development (ZPD), and the more experienced individual/scaffolding (Vygotsky, 1978).

Vygotskian based theorists, Bodrova and Leong (2015), explain that social interactions take place when two individuals interact and communicate with one another. The zone of proximal development (ZPD) refers to the space between a child's lack of understanding, and their mastery of a task or concept; scaffolding refers to a higher-level individual guiding a child to understanding. Therefore, for scaffolding to occur, children must interact with individuals of a higher developmental level. It is through scaffolding that children experience developmental growth (Bodrova \& Leong, 2015). Vygotsky placed great emphasis on the study of pretend play during early childhood, because during pretend play children can interact with a higher-level peer or teacher (Vygotsky, 1978). It is during these interactions that children can reach higher levels of developmental growth and understanding. Vygotsky believed that pretend play is not feasible in children younger than three because they have not yet developed the necessary cognitive and social skills, thus age is a key aspect of pretend play (Vygotsky, 1978). 
Howes (2011) explained that it is during the preschool years that children become more social; spending less time engaging in parallel play, which involves simply playing alongside one another, rather than with one another; and begin spending more time interacting with others through social forms of play (Howes, 2011). This newfound social interaction provides children with experiences supporting their social learning (Howes, 2011). While all children seem to develop more social behaviors during the preschool years, there are characteristics that influence who a child will play with, and the types of behaviors and play forms the child will participate in, bring us to the discussion of gender (Howes, 2011).

It is through play that one often notices that girls and boys begin to behave differently; Girls engage in more creative play, while boys engage in more acts of rough and tumble play (Lindsey, 2012). Lindsey (2012), conducted a study assessing gender differences taking place during naturally occurring peer play. The authors discovered that children spent more time interacting with same sex peers, and that girls participated in significantly more socio-dramatic play than boys, and boys participated in higher amounts of rough and tumble play than girls (Lindsey, 2012). Martin and Fabes (2001) reported similar findings. A large majority of social interactions during preschool occur during play but preschoolers do not play with all peers equally. Gender is one of the largest influencers behind who a child chooses to play with (Martin \& Fabes, 2001). When choosing a play partner, girls typically choose girls, and boys will typically choose boys. This is due to the understanding that young children often feel more comfortable with those who seem to be similar to one's self (Martin \& Fabes, 2001). This idea of children preferring peers of the same gender is known as gender segregation and has been seen across cultures as a significant influencer on peer choice across the lifespan (Mehta \& Strough, 2009). 
There are disparities among researchers on why there are gender differences seen in play behaviors, and Martin et al. (2011) discussed their beliefs on the matter. The authors suggest that gender segregation occurs due to early behaviors related to reproductive success and roles. The authors believed that males and females have different evolutionary roles and these roles may influence gender segregation. The authors explain that sexual selection, a phenomenon which describes the selection of mates who will ensure reproductive success, wants males who are stronger, and more likely to achieve reproductive success. Sexual selection favors females who are able to nurture and care for their offspring. Because of these evolutionary differences between males and females, the different genders also display differing social and play behaviors (Martin et al. 2011). Boys often engage in more active, rough and tumble play, possibly due to their evolutionary need to be strong enough to compete with other males (Maccoby, 2000). On the other hand, females engage in social, cooperative play which could stem from and evolutionary need to care for their offspring (Maccoby, 2000.)

Basow (2010) pointed out that research conducted on gender differences in the brain is often seen as controversial. For example, Saucier and Ehresman (2010) discussed the idea that prenatal sex hormones can cause structural differences within the brain, and Maccoby (2000) believed that gender differences were based on evolutionary needs. Basow (2010) discussed the gendered classroom and the idea that gender reaches beyond biology and is influenced by the environmental factors children are exposed to during early childhood (Basow, 2010). Due to the differences that researchers such as Lindsey (2012) have pointed out regarding males and females, the current study aimed to address whether males and females assess their pretend play differently. With that, the characteristics of pretend play were discussed.

\section{Characteristics of Pretend Play}


Leong and Bodrova (2012), theorists who use Vygotsky's theories to support their research on pretend play, believe that pretend play is created when children engage in social interactions with others to create their own imaginary scenarios (Leong \& Bodrova, 2012). Bodrova and Leong (2003) discuss characteristics fundamental to make-believe-play consisting of: language development, roles, clearly defined rules, flexible themes, and time (Bodrova \& Leong, 2001). For children to successfully engage in pretend play, they must be able to include these characteristics.

The first characteristic listed, language development, is an important aspect of pretend play because it is how children communicate with one another. During pretend play, children communicate with peers of a similar age, as well as peers who are older (Berk, 1994). Through these interactions and relationships, children develop distinct, and imaginary situations (Vygotsky, 1978). To develop strong language skills, children need to practice having back and forth conversations with adults, as well as children their own age. One way that children can do this is through pretend play (Weisberg, Zosh, Hirsh-Pasek, and Golinkoff, 2013). When participating in pretend play, children create their own roles and scenarios using relevant vocabulary. To do this, children must know and understand relevant vocabulary, and this is where the importance of higher level peers comes into play. Socializing with a peer of a higher developmental level provides children with the opportunity to hear new vocabulary words, scaffolding their language development (Berk \& Winsler, 1995).

The second characteristic of pretend play, roles, allows children to think through their past and present experiences to create the setting of their (Bodrova \& Leong, 2012). The development of roles provides children a better understanding of that real-life role. Children will create their own characters in an imaginary scenario, characters which will fuel the entire play experience. 
To foster a child's sense of curiosity and learning as they engage in self-directed play, adults should create an environment where children can engage in various thematic roles by creating a positive social environment, full of props and manipulatives. It is through the play environment that children have the means to create their own worlds, scenarios, roles, and outcomes (Elkind, 2008); and it is during these experiences that children can integrate their existing knowledge of characters into new settings and scenarios, expanding their understanding of real life roles (Bodrova \& Leong, 2003).

The third characteristic of pretend play, rules, are a necessary aspect of pretend play because they govern the play experience. While developing rules, children process and learn more about the diplomatic world they live in. Children often discover self-regulation during pretend play because they are required to suppress inappropriate desires. During the play experience children are confined to the rules of the role they are playing, and supports their self-regulation (Vygotsky, 1978). To help children engage in these high levels of play over an extended period, teachers can work with the children to plan their play (Bodrova \& Leong, 2003).

The fourth characteristic of pretend play is time (Bodrova \& Leong, 2003). Children need an adequate amount of time to fully engage in and understand the roles they create. It often takes days to reach the higher-level mature play necessary for developmental growth (Bodrova \& Leong, 2003). Adequate amounts of time to engage in pretend play also helps children to develop higher levels of self-regulation (Bodrova, Leong, Henson, \& Herringer, 2000). When entering their pre-school years, children begin to realize their inability to instantly gratify many of their desires, and they are able to practice self-regulation through the development of rules in pretend play (Bodrova et al., 2000; Vygotsky, 1978). Before children engage in pretend play, teachers should provide children with adequate amounts of time to plan their play. Planning play 
requires children to think ahead about what they will be playing, as well as the roles they will be participating in. This process is described as completing a play plan (Bodrova \& Leong, 2001). Planning play experiences ahead of time allows children to gain a deeper understanding of the role they choose and physically documenting the play plan onto paper helps children to fully understand the rules of their self-chosen role. As children learn about and enact these rules and roles, they are further developing their regulatory capabilities (Bodrova \& Leong, 2001).

To aid in the planning of play, Leong and Bodrova (2012) discuss the use of play plans. Play plans involve children choosing a role or activity and writing about how they will enact that role. By helping children plan their play, teachers are forcing them to think about the rules of the role they choose. Children can begin to think abstractly about situations that have not yet occurred. Having children draw their play plan helps them develop a deep interest and understanding of their self-chosen role (Leong \& Bodrova, 2012). Play plans are not only beneficial to the child, they allow teachers and parents to participate in a child's play experience. When children physically document their plan for play, parents and teachers can go through and discuss what the child has been playing. Play plans also allow the teacher to engage with their student on a more personal level (Bodrova \& Leong, 2001).

The laboratory school where the participants of the study attended utilized play plans as a part of their classroom curriculum. Warash and Workman (2016), staff present at the laboratory school, incorporated play plans into their curriculum to provide children with an opportunity to plan what they wanted to play that day. With the help of a teacher, children drew what they were going to play, and wrote their ideas on their play plan. The teachers encouraged children to come up with a plan which stimulated involvement in that activity (Warash \& Workman, 2016). 
Teachers, parents, and higher-level play mates can help children include each of Leong and Bodrova's (2003) characteristics of pretend play into their play experiences. It is important to remember that adults taking full control of a play situation takes away the child's opportunity to plan roles and create rules, while eliminating yourself from play takes away your opportunity to scaffold children to higher levels of engagement and learning (Ceglowski, 1997; Bodrova \& Leong, 2003). To help children take advantage of the learning outcomes associated with higher level pretend play, adults should create an environment which allows children to interact with props, supports role development, and provides ample time for planning play (Bodrova \& Leong, 2003). Children planning play by drawing and writing about their ideas on paper and reviewing their plans seems to be the first step towards children assessing their own work.

\section{Children's Use of Self-Assessment}

The current study aimed to address whether children can assess their own play. Similarly, Studwell and Moxley (1984), as well as Stipek, Recchia, and McClintic (1992) have conducted various studies on self-evaluation and academic achievement in young children. Stipek, Recchia, and McClintic (1992) analyzed a group of children between the ages of one and five. The authors proposed that children's critique of their academic performance can elicit varying emotions. When children do not see themselves as doing well they can become helpless, and when they view themselves as sufficient, it can influence their desires to complete academic tasks.

Allowing children to set their own goals could motivate them, while having a parent set the goal could cause children to become stressed (Stipek, Recchia, \& McClintic, 1992).

Warash and Workman (2016), implemented rubrics into their laboratory classroom to provide the children with a way to evaluate their work. The authors had previously set in place various ways for children to keep track of their achievements, utilizing play plans and contracts 
as forms of goal setting with their students. They believed that after providing these forms of self-recording in their classrooms, that the next step was to provide the children with a way to evaluate their work. Children were taught to evaluate their work on a scale consisting of "1" which meant minimal effort, "3" representing good effort, and " 5 " signifying the best work ever. The children's use of the self-assessment rubric allowed them to express their thoughts and opinions of their work. Using self-assessment provided the children with the ability to evaluate their work and encouraged them to discuss areas in which they could improve. The authors also highlighted the fact that when using self-assessment, children did not have to fear the ridicule or judgement of a teacher analyzing their work (Warash \& Workman, 2016).

In line with the research above, the current study employed the use of young children assessing their perception of play. Sturgess (2002), the author and creator of the Play Skills SelfRepot Questionnaire, the measure utilized in the current study, believed that understanding and listening to how children perceive their own play would be the best option for fully assessing and understanding how play perceptions can change over time (Sturgess, 2002). It seemed logical that if children can successfully assess their own drawings and other academic work they could self-assess their pretend play, therefore, the current study addressed the preschool children's perceptions of pretend play.

\section{Current Study}

The current study aimed to address the feasibility of young children self-assessing their pretend play. Taking into consideration the developmental progress occurring between the ages of three and four, and again between the ages of three and five, as well as the influence gender has on children's play preferences, the following research questions were addressed during the study: 1) Do males and females assess their play reliably, and what is the reliability for males 
and females? 2) Does a child's age influence how they assess pretend play? More specifically, will children enrolled in a preschool class for three and four-year old children assess their pretend play differently than children enrolled in a preschool class for four and five-year old children? 3) Does a child's gender influence how they assess pretend play?

\section{Chapter II}

\section{Participants}

\section{Method}

Thirty-nine preschoolers attending a university laboratory school in a small city were questioned on their perceptions of play using the Play Skills Self-Report Questionnaire (PSSRQ). Most children in the study came from higher SES families. This school implements a project-based curriculum and a large portion of the school day consists of children making their own choices during free play and center time. Teachers encourage pretend play by creating a weekly learning center which involves roles and providing the children with corresponding props. The students begin their day by completing play plans and are provided a list of roles, which are related to that week's learning center. Teachers help the children plan their play by discussing the rules of each role. The children choose who they want to be, and physically document their choice by drawing a picture and providing a dictation of the activity.

After obtaining IRB approval, data collection began. During data collection, the students were enrolled in either the three or four-year old classroom. A total of 39 students (18 boys, 21 girls) participated in the study. Data was collected across time, as the children moved from the three-year old class, to the four-year old class.

\section{Procedure}

Children between the ages of three and four, enrolled in a university laboratory school were asked to participate in the study. The children made up two classes, the three-year-old class, and 
the four-year-old class. After obtaining necessary IRB approval, consent forms for the study were sent out to parents. Children were individually interviewed on their perceptions of how they play using the Play Skills Self-Report Questionnaire (PSSRQ). Interviews occurred in the Spring and again in the Fall for both classes. During time one and time two, the questionnaire was administered by the researcher, in a secluded area of school with minimal distractions. The researcher started the assessment by asking the children what they liked to play at school, at home, and with their friends or siblings. Once the researcher felt the child was comfortable talking about play, the questionnaire was administered. The data was collected in two waves, separated by gender, whether they were enrolled in the three or four-year-old class.

\section{Measures}

The Play Skills Self-Report Questionnaire (PSSRQ) (Sturgess, 2002) was used to assess children's perceptions of their play behaviors. The questionnaire consists of 29-items rated on a four- point scale, represented by stars. The current study used the questions regarding Pretend Play and included 14 out of the 29 items on the questionnaires (See Appendix A). The rating scale for the questionnaire ranged from Not Good to Very Good, with stars increasing in size to represent a higher score. Children were instructed to point to the star which most represented how they felt in response to the question. The Play Skills Self-Report Questionnaire (PSSRQ) was originally designed to question five-10-year-old children on their personal assessment of their ability to play. The questionnaire allows children to track their perceptions of play across time. The questionnaire examined types of play (pretend, exploratory, functional, constructional/creative, and games with rules), functions of play, support skills, and play contexts. 
Sturgess and Ziviani (1996) conducted a study which included seventy-two children between the ages of four and ten years old. The students, as well as their parents, completed a trial form of the Play Skills Self-Report Questionnaire, to check for test-retest reliability, twenty-two children were retested a month later. Acceptable levels of internal consistency were found, children were found to have stable perceptions over a four-week period (Sturgess \& Ziviani, 1996). Validity of the PSSRQ was supported for children between the ages of five and 10 (Sturgess, 2002), however, the current study used the measure with children between the ages of three and five.

\section{Analysis Plan}

To answer research question number one, the researcher calculated Cronbach's alpha for the three and four-year old classes. Reliability was assessed separately for both age, and gender, with acceptable reliability set at ( $\alpha=.70$; Trobia, 2008). To answer research question two, the researcher employed a repeated measures design ANOVA and assessed whether age was a statistically significant variable in determining pretend play self-assessment scores. Scores were compared across time to observe if there are any differences between children in the three-yearold class and children in the four-year-old class. To answer question number three, the researcher employed a repeated measures design ANOVA to observe whether gender was a statistically significant variable in determining the self-assessment scores of pretend plays in the three and four-year-old class. The researcher analyzed the data to determine if boys and girls in the threeyear-old and four year old classes changed over time and whether boys and girls scored themselves differently.

\section{Chapter III}

\section{Results}

\section{Research Question One}


To address research question one, Cronbach's Alpha was calculated. The pretend play measures consisted of 14 items. The questionnaire was administered twice, once in the Fall ( $\alpha=.81$ ), and again in the Spring ( $\alpha=.84)$. During Fall data collection, when split by age, the three-year old class (Cohort 1) demonstrated acceptable reliability $(\alpha=.82)$. The four-year-old class (Cohort 2) also demonstrated acceptable reliability ( $\alpha=$.78). During Fall data collection, when split by gender, males demonstrated unacceptable reliability $(\alpha=.58)$. Females demonstrated acceptable reliability ( $\alpha=.83$ ) (see Table 2). During Spring data collection, when split by age, the three-year-old class (Cohort 1) demonstrated acceptable reliability $(\alpha=.81)$. The four-year-old class (Cohort 2) also demonstrated acceptable reliability $(\alpha=.88)$. During Spring data collection, when split by gender, females showed acceptable reliability $(\alpha=.85)$. Males also showed acceptable reliability ( $\alpha=.84)$ (see Table 2 ).

\section{Research Question Two}

To address research question two, a two-way repeated measures ANOVA was conducted. The within-subjects design showed that there was no difference on how the two classes assessed their play between Fall and Spring $(F(1,34)=0.53, p=.47)$, and there was no difference in scores between Fall and Spring $(F(1,34)=.89, p=.35)$. The between subject's design showed that being in the three or four-year-old class was not a statistically significant predictor of assessment scores, $(F(1,34)=1259.01, p=.25$ see Table 3$)$.

\section{Research Question Three}

To address research question three, a two-way repeated measures ANOVA was conducted. Within-subject's effects showed that there was no difference on how males and females assessed their play between the Fall and the Spring $(F(1,34)=2.15, p=.15)$. However, while there were no differences within students between the pretest and the posttest $(F(1,34)=.65 p=.43)$, the 
between subject's effect showed that there were differences in self-assessment scores between males $(\mathrm{M}=3.42, \mathrm{SD}=.38)$ and females $(\mathrm{M}=3.06, \mathrm{SD}=.60 ; F(1,34)=4.47, p=.04$; see Table 4).

\section{Discussion}

Research question one asked how reliable scores were for three-year-old children versus four-year-old children. Results showed that in the Fall, children enrolled in the three-year-old class, and children enrolled in the four-year-old class, demonstrated acceptable reliability. The same was found for data collected in the Spring, three-year-old children and four-year-old children could reliably assess their play. This ability to reliably assess play could be due to the developmental growth taking place during the preoperational stage of development (Rothbart \& Rueda, 2005). Three-year-old children have just entered this stage of development and are beginning to develop the ability to think abstractly about past and present situations. Throughout this stage of development as brain growth occurs, children develop the ability to think in more complex ways and may also gain the ability to assess their pretend play experiences (Piaget, 1964; Rothbart \& Rueda, 2005).

A second reason that children could reliably self-assess their play may be that the education levels of the parents at the laboratory school could influence how their children self-assess their play. Ursache and Noble (2016) discussed the influence that social economic status (SES) has on neurocognitive development in young children. A child's SES can influence their linguistic environment, with children coming from higher income families being exposed to a higher number of words (Ursache \& Noble, 2016). Therefore, the children in the study may have been able to reliably assess their play due to the high quality linguistic environment they live in.

The second part of research question one was, are males and females both able to reliably assess their play? Results showed that during the Fall, males demonstrated low reliability while 
females demonstrated acceptable reliability. However, in the Spring, both males and females demonstrated acceptable reliability. Males showing low reliability during the Fall and showing acceptable reliability during the Spring could be due to the developmental growth occurring as they progress through the pre-operational stage of development (Piaget, 1964). The difference in reliability seen between males and females could be due to females spending more time engaging in social forms of play while boys spend more time engaging in rough and tumble play (Lindsey, 2012). While engaging in more social pretend play experiences, girls may be fostering the skills they need to effectively and reliably assess their pretend play. Environmental factors, such as parenting practices, or classroom structure may also influence how males and females perceive and assess their pretend play (Lindsey, 2012). Parents and teacher's beliefs on gendered play may shape how girls and boys participate and think about pretend play (Sompel et al., 2012). Sompel et al. (2012) found that children's toy preferences aligned with the parents measure of how often the child played with certain toys. This supports the idea that gender prejudices may influence how, what, and who children play with, which could potentially influence how they assess their pretend play (Sompel, 2012).

The second research question stated, "Does age influence how children will assess their pretend play?" There was no difference in how the three-year-old class performed compared to the four-year-old class, between the Fall and Spring data collection periods. Children in the three-year-old class did not perform differently than children in the four-year-old class. This could be due to changes in play that have taken place over time (Bodrova \& Leong). Bodrova and Leong (2003) say children may have more difficulties learning to play and engage in the "roles" found in pretend play due to changes in the age groups of children that play together. In the past, children spent time playing with other children in their neighborhoods who varied in 
ages so younger children learned to play by watching the higher functioning level of older playmates. Currently, children spend more time playing video games and using other forms of technology, as well as playing with same age peers (Bodrova \& Leong, 2003). Bodrova and Leong (2003) discuss the importance of older children scaffolding younger children to higher levels of play, and without these higher-level peers to be role models, children may not be reaching the quality, imaginative play of the past. Children involved in the study attended a classroom of same age peers and did not have those older role models to give them a rich perspective on pretend play, so they could respond to the questions more accurately.

Research question three addressed whether males and females assess themselves differently on the PSSRQ. Results showed that there was no difference in how males and females assessed their play between fall and spring. However, without looking at time, males did assess their play differently than females. When looking at mean scores, Males $(\mathrm{M}=3.42, \mathrm{SD}=.38)$ scored themselves higher assessment than females $(\mathrm{M}=3.06, \mathrm{SD}=.6)$. There are two reasons this could be. First, during data collection, females spent more time assessing their play than males. Obtained from field notes collected during the administration of the questionnaire, it was revealed that girls spent more time answering the questions and provided more dictations and conversation about their answers than boys in either class did. Boys answered more succinctly and often stated that they were more likely to be good at everything and offered less conversation. Males receiving higher scores may be due to their lack of time spent answering each question and their belief that they were already masters in each area of play. The females in the study may have spent more time thinking through the questions and their past experiences, and therefore scored themselves lower. The age of the males and females could also influence 
how they assessed their play, but unfortunately, the study did not have the power to assess whether the age of the males and the age of the females influenced their responses.

Second, environmental and social factors such as parent and teacher beliefs on gender and pretend play may be inadvertently influencing how children think about, and engage in play (Lindsey, 2012). If parents and teachers encourage girls to participate in social pretend play, while encouraging males to participate in rough and tumble play, it could influence how males and females perceive play, and in the case of this study, pretend play.

\section{Limitations}

The study had several limitations. Because of the limited number of participants, the study may have been underpowered to find effects. In addition, the population was predominantly professional and considered middle class. Because of the homogeneous group and limited number of participants, any results may be not generalizable. In this study, the PSSRQ was used with younger children than it was intentionally designed for. The PSSRQ was not developed for three and four-year-old children. It was also developed in Australia and not the United States (Sturgess, 2002) and some of the questions had non-familiar wording that pertained more to the common vernacular in Australia. For example, question 29 read, "Are you good at playing cubby or tree-house games?" These are not commonly used words in the United States and are confusing for young children.

\section{Application}

Although the findings in this study were limited, there is some evidence that, at least in this sample, three and four-year-old children could assess their pretend play. The differences in how males and females self-assess pretend play should be further studied and used by educators to create classroom curriculums. Teachers could use the Play Skills Self-Report Questionnaire 
(PSSRQ) to evaluate how male and female students are self-assessing play and could then use this information to shape their classroom curriculum. The findings of this study could also be used to inform parents of the differences in how males and females self-assess their play. Providing parents with research on gender differences in pretend play could be used to help them encourage their children to engage in appropriate pretend play (Sturgess, 2002).

\section{Future Directions}

In the future, researches should further address the differences between males and female's perceptions and assessments of pretend play. Because pretend play influences early childhood development (Vygotsky, 1978), future researchers should look at and design curriculums which incorporate pretend play into classrooms, concentrating on developing a curriculum that appropriately engages males and females into pretend play experiences. Future researchers should also further study developmental reasons behind why males and females self-assess play differently. Understanding why there are gender differences in pretend play can help educators and parents to provide children with the proper experiences to facilitate developmentally appropriate pretend play.

\section{Conclusion}

The current study found that three and four-year-old children could reliably self- assess their play. The study also found that collapsing across time, males and females self-assess their play differently. Theorists such as Piaget (1964) and Vygotsky (1978) support the inclusion of pretend play in early childhood education due to the developmentally appropriate skills and behaviors children receive and exhibit through pretend play experiences. While the study's findings were limited, the differences found between males and females self-assessment scores supports future research concerning gender differences in play. Overall, research on pretend play should be 
further studied, and future research should concentrate on how to include developmentally appropriate play into the homes and classrooms of young children. 


\section{References}

Ahn, J., \& Filipenko, M. (2007). Narrative, imaginary play, art, and self: Intersecting worlds. Early Childhood Education Journal, 34(4).

Basow, S. A. (2010). Handbook of Gender Research in Psychology, 277-295.

Berk, L. E. (1994) Vygotsky's theory: The importance of make-believe play. Young Children, (11)30-39.

Berk, L. E., \& Winsler, A. (1995). Scaffolding children's learning: Vygotsky and early childhood education. Washington: National Association for the Education of Young Children.

Bodrova, E., Leong, D., Hensen, R., \& Henninger, M. (2000). Imaginative, child-Directed play: Leading the way in development and learning. Dimensions of Early Childhood, 28(4), 25-30.

Bodrova, E. \& Leong, D.J. (2001). Tools of the mind: A case study of implementing the vygotskian pproach in american early childhood and primary classrooms.

Bodrova, E., \& Leong, D. (2003). Chopsticks and counting chips: Do play and foundational skills need to compete for the teacher's attention in an early childhood classroom? Young Children, 58(3), 10-17.

Bodrova, E. \& Leong, D.J. (2003). Understanding and building upon children's perceptions of play: Activities in early childhood programs. Early Childhood Education Journal, 25(2).

Bodrova, E. \& Leong, D.J. (2003). The importance of being playful. Educational Leadership, 60(7), 50 .

Bodrova, E., \& Leong, D.J. (2005). Why children need play. Early Childhood Today, 20(1), 6.

Bodrova, E. \& Leong, D. J. (2015). Vygotskian and post-vygotskian views on children's play. American Journal of Play, 7(3), 371-388. 
Bronfenbrenner, U. (2009). The ecology of human development: experiments by nature and design. Retrieved from https://ebookcentral.proquest.com

Burghardt, G. M. (2011). Defining and recognizing play. The Oxford Handbook of The

Development of Play, 9-18. Editor-in-chief: A. D. Pellegrini, Oxford University Press: NY: New York.

Ceglowski, D. (1997). Understanding and building upon children's perceptions of play: Activities in early childhood programs. Early Childhood Education Journal, 25(2).

Cohen, D. (1993). The development of play (2nd ed. ed., Concepts in developmental psychology). London: Routledge.

E. E. Maccoby. (2000). Parenting and its effects on children: On reading and misreading behavior genetics. Annual Review of Psychology, 51, 1-27.

Leong, D. J., \& Bodrova, E. (2003). Playing to learn. Scholastic Parent \& Child, 11(2), 28.

Leong, D. J., \& Bodrova, E. (2003). Self-regulation in the early childhood classroom. Early Childhood Today, 18(1).

Leong, D. J., \& Bodrova, E. (2012). Asessing and scaffolding: Make-believe play. Young Children, 67(1), 28-34.

Martin, C. L., \& Fabes, R. A. (2001). The stability and consequences of young children's samesex peer interactions. Developmental Psychology, 37(3), 431-446.

Martin, C., Fabes, R., Hanish, L., Leonard, S., \& Dinella, L. (2011). Experience and expected similarity to same gendered peers: Moving toward a comprehensive model of gender segregation. Sex Roles, 65(5-6), 421-434.

Miller, E., \& Kuhaneck, H. (2008). Children's perceptions of play experiences and play preferences: A qualitative study. The American Journal of Occupational Therapy, 63(4). 
Montessori, M. (1965). The montessori method. Cambridge, Mass: R. Bentley.

Piaget, J. (1952). The origins of Intelligence in children. New York: International Universities Press.

Piaget, J. (1964). Cognitive development in children: Piaget. Journal of Research in Science Teaching, 2(3), 176-186.

Rothbart, M. K., \& Rueda, M. R. (2005). The development of effortful control. In U. Mayr, E. Awh, \& S. W. Keele (Eds.). Developing individuality in the human brain: A tribute to michael i. posner (pp. 167 - 188). Washington, DC, US: American Psychological Association.

Rubin, K. H., \& Pepler, D.J. (1982). Children's play: Piaget's views reconsidered. Contemporary Educational Psychology, 7(3), 289-99.

Saucier, D., \& Ehresman, C. (2010). The Physiology of Sex Differences. In J. C. Chrisler \& D. R. McCreary (Eds.), Handbook of Gender Research in Psychology: Volume 1: Gender Research in General and Experimental Psychology (pp. 215-233). New York, NY: Springer New York.

Stipek, D., Recchia, S., \& McClintic, S. (1992). Self evaluation in young children. Monographs of the Society for Research in Child Development, 57(1), 1-84.

Studwell, P., \& Moxley, R. (1984). Self-recording in kindergarten: A study in naturalistic evaluation. Psychology in the Schools, 21(4), 450-56.

Sturgess, J. (2002). Children's play skills self-report questionnaire.

Sturgess, J., \& Ziviani, J. (1996). A self-report play skills questionnaire: Technical development. Australian Occupational Therapy Journal, 43(3-4), 142-154.

Sutton-Smith, B. (2011). The antipathies of play. The Oxford Handbook of The Development of 
Play, 110-118. Editor-in-chief: A. D. Pellegrini, Oxford University Press: NY: New York.

Sutton-Smith, B. (1997). Play and ambiguity. In The ambiguity of play (pp. 1-17). Harvard University Press.

Theobald, M., Danby, S., Einarsdottir, J., \& Bournem J (2015). Children’s percpectives of play and learning for educational practice. Education Sciences, 5(4), 345-362.

Trobia, A. (2008). Cronbach's alpha. In P. J. Lavrakas (Ed.), Encyclopedia of survey research methods (pp. 169-170). Thousand Oaks, CA: SAGE Publications Ltd.

Ursache, A., \& Noble, K. (2016). Neurocognitive development in socioeconomic context: Multiple mechanisms and implications for measuring socioeconomic status. Psychophysiology, 53(1), 71-82.

Van de Sompel, D., Vermeir, I., \& Pandelaere, M. (2012). Gender differences in children's creativity and play behaviors. In S. P. McGeown (Ed), Psychology of Gender Differences (59-76). New York: Nova Science.

Vygotsky, L. (1978). Mind in society: The development of higher psychological processes. Cambridge, Ma: Harvard University Press.

Warash, B., \& Workman, M. (2016). Teaching preschoolers to self-Assess their choices in preK. Journal of Educational Research and Practice, 6(1), 97-104.

Weisberg, D., Zosh, J., Hirsh-Pasek, K., \& Golinkoff, R. (2013). Talking it up: Play, language development, and the role of adult support. American Journal of Play, 6(1), 39-54.

Wing, L.A. (1995). Play is not the work of the child: Young children's perceptions of work and play. Early Childhood Research Quarterly, 10(2), 223-246. 
Table 1

Means and Standard Deviations of Pretend Play Variables Assessed Across Time

\begin{tabular}{llllllll}
\hline & \multicolumn{3}{l}{ Fall 2016 } & \multicolumn{5}{c}{ Spring 2017 } \\
\hline \multirow{3}{*}{3 and 4 } & & N & $\underline{\mathrm{M}}$ & $\underline{\mathrm{SD}}$ & $N$ & $\underline{\mathrm{M}}$ & $\underline{\underline{\text { SD }}}$ \\
& $\mathrm{M}$ & 20 & 3.31 & .61 & 20 & 3.34 & .61 \\
& $\mathrm{~F}$ & 10 & 3.52 & .296 & 10 & 3.27 & .72 \\
\multirow{3}{*}{4 and 5 } & All & 10 & 3.09 & .76 & 9 & 3.40 & .51 \\
& $\mathrm{M}$ & 7 & 3.01 & .67 & 16 & 3.22 & .77 \\
& $\mathrm{~F}$ & 10 & 3.34 & .55 & 7 & 3.53 & .51 \\
& & & 2.76 & .65 & 9 & 2.98 & .88 \\
\hline
\end{tabular}


Table 2

Reliability Statistics- Fall 2016 and Spring 2017

\begin{tabular}{|c|c|c|c|c|}
\hline & Section & $\begin{array}{l}\text { Cronbach's } \\
\text { Alpha }\end{array}$ & $\begin{array}{l}\text { Cronbach's Alpha } \\
\text { Based on } \\
\text { Standardized Items }\end{array}$ & $\mathrm{N}$ of Items \\
\hline \multirow{4}{*}{$\begin{array}{l}\text { Fall } \\
2016\end{array}$} & $\begin{array}{l}3 \text { yr. old } \\
\text { class }\end{array}$ & .82 & .81 & 14 \\
\hline & $\begin{array}{l}4 \text { yr. old } \\
\text { class }\end{array}$ & .78 & .76 & 14 \\
\hline & Males & .58 & .50 & 14 \\
\hline & Females & .83 & .83 & 14 \\
\hline \multirow{4}{*}{$\begin{array}{l}\text { Spring } \\
2017\end{array}$} & $\begin{array}{l}3 \text { yr. old } \\
\text { class }\end{array}$ & .81 & .82 & 14 \\
\hline & $\begin{array}{l}4 \text { yr. old } \\
\text { class }\end{array}$ & .88 & .88 & 14 \\
\hline & Males & .84 & .84 & 14 \\
\hline & Females & .85 & .85 & 14 \\
\hline
\end{tabular}


Table 3

Analysis of Variance Results for Cohort and Time

\begin{tabular}{|c|c|c|c|c|c|}
\hline Source & $d f$ & $S S$ & $M S$ & $F$ & $p$ \\
\hline $\begin{array}{l}\text { Cohort } \\
\text { Cohort x Time } \\
\text { error }\end{array}$ & $\begin{array}{l}1 \\
1 \\
34 \\
\end{array}$ & $\begin{array}{l}\text { hin Sub } \\
.27 \\
.16 \\
10.38 \\
\end{array}$ & $\begin{array}{l}.27 \\
.16 \\
.31 \\
\end{array}$ & $\begin{array}{l}.89 \\
.53\end{array}$ & $\begin{array}{l}.35 \\
.47\end{array}$ \\
\hline $\begin{array}{l}\text { Cohort } \\
\text { Error }\end{array}$ & $\begin{array}{l}1 \\
34 \\
\end{array}$ & $\begin{array}{c}\text { een Sul } \\
.80 \\
19.85 \\
\end{array}$ & $\begin{array}{l}.80 \\
.58 \\
\end{array}$ & 1259.01 & .25 \\
\hline
\end{tabular}

$* \underline{p}<.05$. 
Table 4

Analysis of Variance Results for Gender and Time

\begin{tabular}{llcccc}
\hline Source & $d f$ & $S S$ & $M S$ & $F$ & $P$ \\
\hline \multirow{5}{*}{ Time } & 1 & Within Subjects & & & \\
time x gender & 1 & .19 & .19 & .65 & .43 \\
error & 34 & .63 & .63 & 2.15 & .15 \\
\hline \multicolumn{5}{c}{ Between Subjects } \\
Gender & 1 & 2.40 & .29 & & \\
error & 34 & 18.26 & 2.40 & 4.47 & $.04 *$ \\
\hline
\end{tabular}

* $p<.05$. 


\section{Appendix A}

Pretend Play Questions Used

Question 3: Are you good at playing with a group of other kids?

Question 4: Are you good at trying to fix up arguments or fights when you are playing with other kids.

Question 8: Are you good at finding something to play with just one other kid?

Question 9: Are you good at being careful when you play with little things?

Question 12: Are you good at finding something to play when you want to make yourself feel happier/better?

Question 13: Are you good at getting into a game that other kids have already started playing?

Question 15: Are you good at rough and tumble play for fun?

Question 16: Are you good at making yourself and others laugh when you play?

Question 17: Are you good at talking with your friends about a game while you are playing?

Question 19: Are you good at making up ideas for pretend games?

Question 21: Are you good at pretending to be someone or something else when you play?

Question 26: Are you good at playing outside - At home, in parks, in playgrounds?

Question 28: Are you good at playing quiet inside games?

Question 29: Are you good at playing cubby or tree-house games? 


\section{Appendix B}

\section{Weirdly Worded Question}

Question 29: Are you good at playing cubby or tree-house games? 